\title{
Geoheritage and Geotourism Potential of the Strzelin Hills [Sudetic Foreland, SW Poland]
}

\author{
Solarska Anna ${ }^{A *}$, Jary Zdzisław ${ }^{A}$ \\ Received: November 2010 | Revised: December 2010 | Accepted: December 2010
}

\begin{abstract}
The aim of this paper is to present a state of knowledge about geotourism potential of the Strzelin Hills. Still there is no geotouristic infrastructure in the Strzelin Hills that could make available all their advantages for educational purposes. There are being carried out works on inventory and documentation to create a base for a development of geotourism.

The geotouristic potential is described on the basis of previously studied and valorized objects of geological and geomorphological heritage. There were inventoried 38 objects of geoheritage. During valorization of 17 geosites and geomorphosites were selected 8 represented objects, which present 10 from the 15 thematic groups. There were briefly described 6 of them in this paper.
\end{abstract}

Key words: valorization of geoheritage, geotourism, geosites, geomorphosites, the Strzelin Hills, SW Poland

\section{Introduction}

The Strzelin Hills is a microregion in south western Poland, precisely within the Niemcza-Strzelin Hills, in the eastern part of the Sudetic Foreland (Figure I A). There is a considerable diversity of geological structure and relief of terrain, as well as the geomorphological transformation or changes in the landscape connected with settlement and agro-industrial economy. Geoheritage of the Strzelin Hills makes up an enormous variety of natural or semi-natural objects and technical monuments located in a relatively small area $\left(\mathrm{I} 92.5 \mathrm{~km}^{2}\right)$. The grounds for selection of geosites and geomorphosites, which are valuable in the local, regional or national scale, are identification, inventory and scientific documentation of identified objects. They are also important for assessment of geodiversity in the area. Additional evaluation of geosites and geomorphosites, in view of accessibility to geotourism and potential visitors interest (research in progress) is necessary, in order to recognize their actual value for geotourism. It creates also opportunities for the protection of geological and geomorphological heritage as a value by its own right.

The most useful forms of inaminate nature protection in Poland are natural monuments, documentary sites of abiotic nature and nature-landscape complex (Dz.U.o9.I5I.I220). In addition an inventories and documentations of geosites on the international and national level are carried out (http://www.iop.krakow.pl/geosites/default. asp, Słomka, et al., 2006). In parallel, there are being prepared also many publications about geological and geomorphological heritage in various scientific centers in Poland (Badura, et al., 2003; Welz, 2005; Knapik, et al., 2007; Radwanek-Bąk, 2009; Alexandrowicz, et al., 2010).

The aim of the paper is valorisation of geological and geomorphological heritage within the Strzelin Hills and presentation a state of knowledge about geotourism potential of them. The research of the Strzelin Hills geoheritage is purposed to preserve state and to raise the scientific awareness and educational value of them.

\footnotetext{
A Department of Geography and Regional Development, University of Wrocław, pl. Uniwersytecki 1, 50-137 Wrocław, Poland

* Corresponding author: Solarska Anna, e-mail: anna.solarska@uni.wroc.pl;

co-author: Jary Zdzisław, e-mail: zdzislaw.jary@uni.wroc.pl
} 


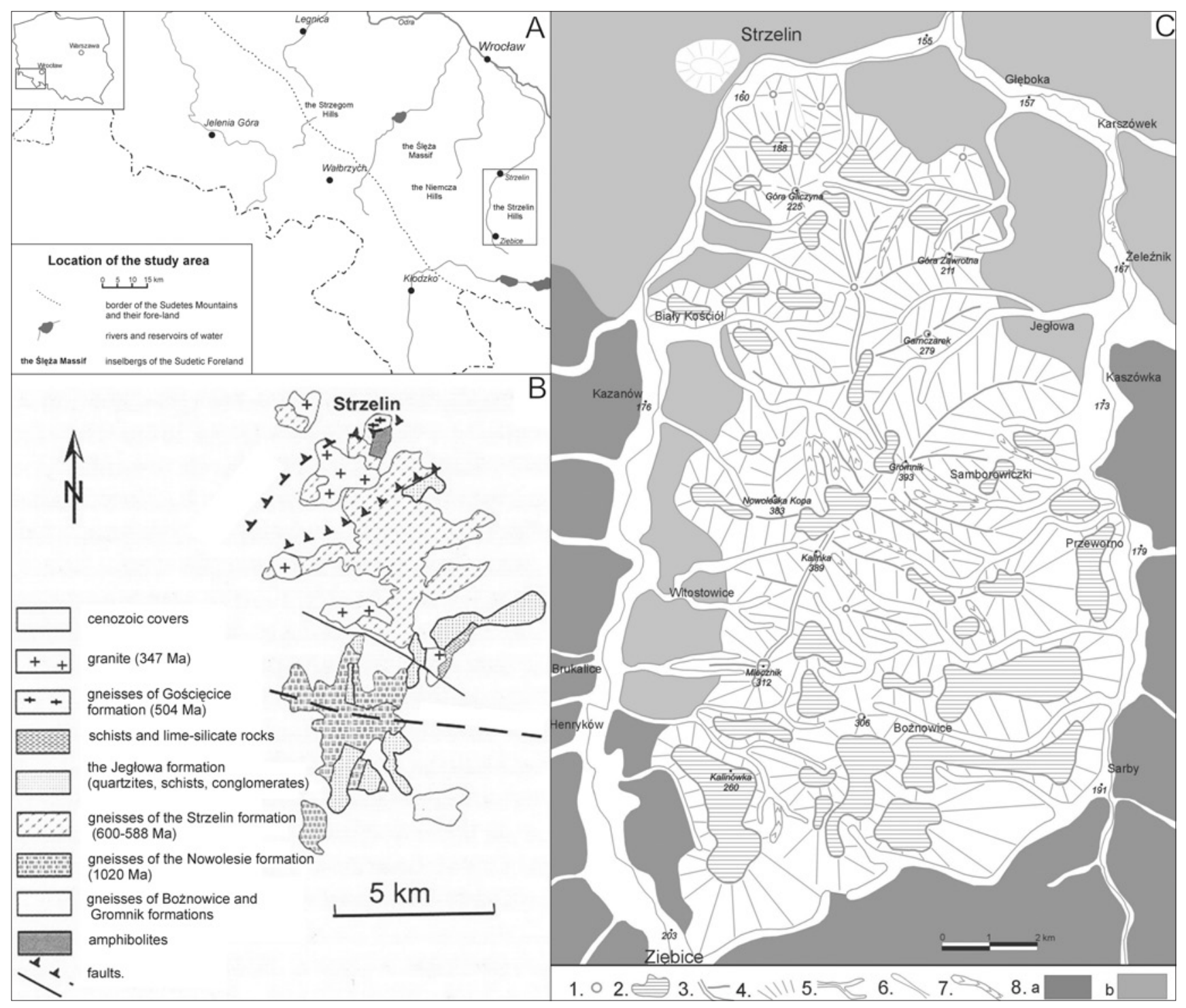

Figure 1. Study area. Explanations: A - location of study area; B - geological sketch of surroundings of the Strzelin Hills [according to Żelaźniewicz, 2005; C - the geomorphology of the Strzelin Hills. Relief developed on solid rocks: 1- summits, 2planation surfaces, 3- ridges [main and second rate ], 4- slopes; Fluvial morphology: 5-valleys, 6-dry valleys, 7- upper parts of valleys [ $\mathrm{V}$-shaped or gullies]; Relief developed on loose rocks [glacial, fluvioglacial, aeolian]: 8- a. hilly plateau, b. glacial plains

\section{Methods}

Initially a variety of cartographic materials were used: German topographic maps (Messtischblatt) published in the I930's in the scale I:25,000, Polish topographic maps made in the I970's and I980's in the scale I:Io,ooo, sheets of Detailed Geological Maps of Sudetes in the scale I:25,000 and aerial photographs in the scale r:26,000. On this background there were selected sites or site-sets, which could be valuable for geologic or geomorphologic science. Inventoried objects were verified and mapped in the fieldwork, which was conducted in 2007-20io.

Selected objects of geoheritage were being examined as potential site or site-sets for geotourism. Objects were assessed in a based on systems applied during inventory and valorization of geosites from Karkonosze National Park and its coat- ing (Knapik, et al., 2009). Objects were evaluated from four main viewpoints of their significance for scientific research, education, accessibility for geotourism and state of preservation. Typological classification of site contains following domains: geochemistry, geomorphology, pedology, history, hydrogeology, cosmogeology, mineralogy, palaeogeography, palaeontology, petrography, sedimentology, stratigraphy, structural tectonic, science of mineral deposits.

The fixed criteria allows to make a statement of every object significance for scientific research and study of their geotouristic and educational functions. The next step is to determine the importance of individual objects. Each criterion has five features. They are diversified for the sake of quality and quantity and have appropriate points weight (Table I). Values of points are divided into 
Table 1. Criteria of assessment for inventoried geosites and geomorphosites [according to Knapik, et al., 2009, modified]

\begin{tabular}{|c|c|c|}
\hline Criterion & Traits & Points \\
\hline \multirow{5}{*}{ Accessibility } & Site clearly visible, located directly on the touristic trail or nature's path & 5 \\
\hline & Site clearly visible, located on the road or path & 4 \\
\hline & Site barely visible, located more than 250 m away from the path or road & 3 \\
\hline & Site difficult to access for tourist [ex. significantly overgrown or difficult to access] & 2 \\
\hline & Site unavailable for tourists & 1 \\
\hline \multirow{5}{*}{ State of preservation } & Well preserved site with no visible signs of degradation & 5 \\
\hline & Site in slight violation of its structure & 4 \\
\hline & Partially destroyed & 3 \\
\hline & Site heavily modified by human & 2 \\
\hline & Site destroyed - loss character of geosites & 1 \\
\hline \multirow{5}{*}{ Scientific worth } & Very high: one site in the region, unique in a wider scale & 10 \\
\hline & High: very important for regional studies & 8 \\
\hline & Average: significant for regional research & 6 \\
\hline & Low: common site with average values & 4 \\
\hline & Very low: no particular distinctive features & 2 \\
\hline \multirow{5}{*}{ Education significance } & Very high: number of represented issues: 5 and more & 10 \\
\hline & High: number of represented issues: 4 & 8 \\
\hline & Average: number of represented issues: 3 & 6 \\
\hline & Low: number of represented issues: 2 & 4 \\
\hline & Very low: number of represented issues: 1 & 2 \\
\hline
\end{tabular}

two groups: from I to 5 (stroke I) for the degree of availability and state of preservation and from 2 to Io (stroke 2) for the scientific and educational significance. Differentiation of points weight made results of valorization more reliable for the sake of rank of geosites. Accessibility for geotourism and state of preservation individual sites concern the physical characteristic of each object. Two others criteria - scientific worth and education significance - decide on actual features of geosite and geomorphosite. Therefore, this way of assessment of objects for geotourism is crucial to identify sites as geosites and geomorphosites.

There are many systems of assessment, but this one seems to be fair and objective. It takes into consideration every necessary criterion, allowing to evaluate the real significance of the object as a geotouristic attraction of the region.

\section{Study area}

\section{Geological structure and relief of the Strzelin Hills}

The Strzelin crystalline massif is composed of heterogenous gneiss nucleus (Figure I B), which were split by fault in the direction NW-SE (Żelaźniewicz, 2005). They are covered by quartzites and quartzite schists, mica schists, marbles and amphibolites. Metamorphic rocks are intruded by granitoids dated from the Carboniferous pe- riod. The traces of Cenozoic volcanism are situated in the middle of Strzelin Hills. On the surface partially lie degraded clay and fluvioglacial covers formed in Pleistocene. Dust deposits are represented by loess developed during the last interglacial-glacial cycle.

Geology of the Strzelin Hills is representative of the Sudetic Foreland. Crystalline rocks characteristic of Foresudetic Block occur in this small area. Most of them have been exploited. On the loess covers fertile soils were formed. It contributed to agriculture development and affected relief transformations.

Relief of the Strzelin Hills exhibits features of upland morphology (Figure I C). Their wide and flattened ridges unfurl at an altitude of 200-300 $\mathrm{m}$ above sea level were cut by deep valleys. The highest peak is Gromnik (392.6 m above sea level). In source craters dry valleys or gullies were often formed. Strzelin Hills are drained by left-bank tributaries of the Krynka river and right-bank tributaries of the Oława river.

\section{Outline of the settlement}

First traces of settlement were dated from the Neolithic Period (Żerelik, 2002) It was around 5,5 thousands years BP (Teisseyre, I994). The area of forested land has decreased significantly in favour of agricultural crops in the thirteenth-fifteenth centuries (Goliński, 2007). Industry was developed from the fourteenth century based on an availa- 
ble rock resources. In the second half of the eighteenth century an abundance of ponds (around II2) were created (Biały, et al., I974; Strauss, I98I). The main phase of development of the network of settlements occurred at the turn of the nineteenth and twentieth century.

\section{Geosites and geomorphosites of the Strzelin Hills}

\section{Effects of valorization}

During the field research of inventoried objects of geoheritage, from 38 sites -I7 were selected and valorized (Table 2). Examined objects represented Io from the 15 thematic groups. There are following scientific domains: geomorphology, pedology, history, hydrogeology, mineralogy, palaeogeography, petrology, sedimentology, structure geology and mineral deposits. In connection with them, very diverse geomorphological problems in the field of structural geomorphology (tors, inselbergs), fluvial geomorphology (small canyons), geomorphological processes (variety of gullies, dry valleys, mass movement in quarries or pits) prevail. Geological topics are also common, mainly geological structure (petrography, mineralogy). Presence of the historical issues is linked with an interesting, economic past of the Strzelin Hills.

Very high scientific worth as "one in the region and unique in a wider scale" was received by the quarry of quartzite and quartz schist in Jegłowa. There were five objects considered of high scientific value because of their importance for regional studies. Most of the assessed sites were clearly visible and in a good state of preservation.

The results of valorization proved a significant geotouristic potential of the Strzelin Hills. During the assessment four geomorphosites and two geosite were selected as objects that have the greatest value for geotourism. Every site has high or very high scientific value. Two of six objects of geoheritage are clearly visible and are located directly on the touristic trail. Also, two others are very well preserved with no visible signs of degradation.

There are diverse, natural objects in most of them, that can be a study of the geological structure of the Strzelin Hills and the development of their morphology. One object was man-made in connection with mining activities. It is well preserved, so allows to look into the interior of the Earth, and also makes possible to observe the natural geomorphological processes within slopes and rocky walls formed by man.

Table 2. Valorization of geoheritage's objects within the Strzelin Hills

\begin{tabular}{|c|c|c|c|c|c|c|}
\hline \multirow[b]{2}{*}{ № } & \multirow[b]{2}{*}{ Object of geoheritage } & \multicolumn{5}{|c|}{ Criteria } \\
\hline & & Access. & $\begin{array}{l}\text { State of } \\
\text { preserve. }\end{array}$ & $\begin{array}{l}\text { Scientific } \\
\text { worth }\end{array}$ & $\begin{array}{l}\text { Education } \\
\text { significance }\end{array}$ & $\begin{array}{l}\text { Summarized } \\
\text { value }\end{array}$ \\
\hline 1 & Quarry of quartzite and quartz schist in Jegłowa & 4 & 5 & 10 & 10 & 29 \\
\hline 2 & Tors in the Gromnik massif & 5 & 5 & 8 & 10 & 28 \\
\hline 3 & Garnczarek - periglacial morphology & 5 & 4 & 8 & 8 & 25 \\
\hline 4 & $\begin{array}{l}\text { Zuzanka valley - small epigenetic canyon and rock } \\
\text { outcrops }\end{array}$ & 5 & 4 & 6 & 10 & 25 \\
\hline 5 & Gromnik - inselberg and peak changed by settlement & 5 & 5 & 6 & 8 & 24 \\
\hline 6 & Pogródki valley- fluvial forms with gully features & 2 & 4 & 8 & 10 & 24 \\
\hline 7 & Goethe's tors & 3 & 4 & 6 & 10 & 23 \\
\hline 8 & Oxbow lakes and palaeochannels in Krynka valley & 3 & 3 & 6 & 10 & 22 \\
\hline 9 & $\begin{array}{l}\text { Residues of fluvial transformation in the Oława } \\
\text { valley in Henryków connected with the Cistercian } \\
\text { management }\end{array}$ & 5 & 4 & 6 & 6 & 21 \\
\hline 10 & Gullies of Diabelska Kręgielnia & 2 & 5 & 6 & 6 & 19 \\
\hline 11 & $\begin{array}{l}\text { Old dams in the Jegłówka Valley - relics of the } \\
\text { nineteenth century fish ponds }\end{array}$ & 5 & 3 & 4 & 6 & 18 \\
\hline 12 & $\begin{array}{l}\text { Residues of weirs in the Oława valley near Henryków } \\
\text { connected with the Cistercian management }\end{array}$ & 3 & 3 & 8 & 4 & 18 \\
\hline 13 & Witostowice - remains of early medieval fortress & 3 & 1 & 10 & 4 & 18 \\
\hline 14 & Sand pit Żeleźnik & 3 & 3 & 6 & 8 & 17 \\
\hline 15 & Relics of Rankenmühle - mill in Oława valley & 4 & 3 & 4 & 6 & 17 \\
\hline 16 & Valley of Six Ponds - slope modeling by overland flow & 4 & 2 & 4 & 4 & 14 \\
\hline 17 & Relics of mills in Krynka valley & 2 & 2 & 2 & 4 & 10 \\
\hline
\end{tabular}




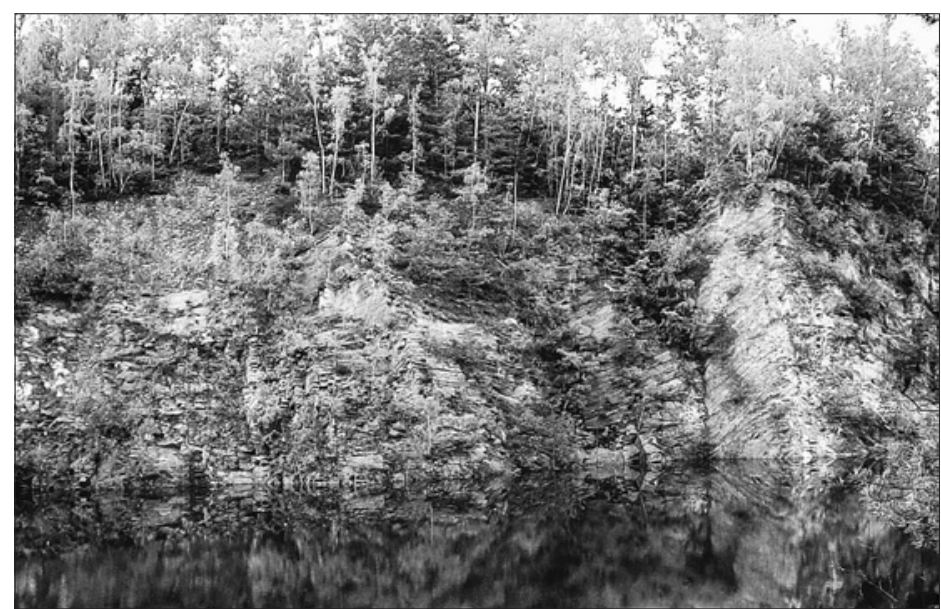

Figure 2. Morphology of bluff in western, unmined part of Jeglowa querry - northern bluff as a cliff-like form [Photo by A. Solarska]

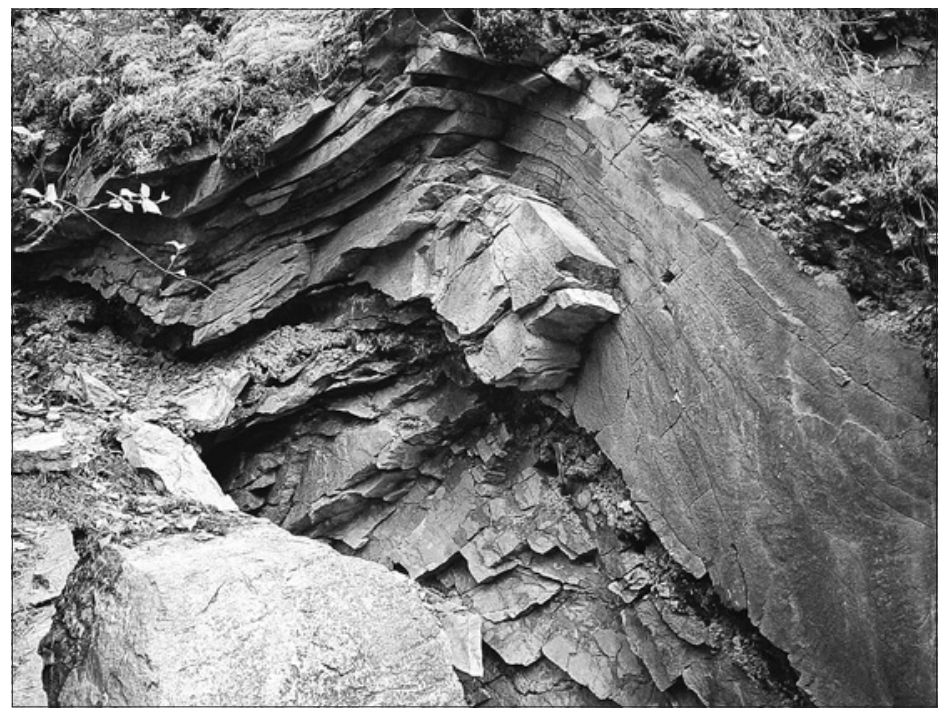

Figure 3. Outcrops of quartzites and quartzite schists within southern bluff in umined part of Jeglowa querry - a fold structure built by rocks of different strength to weathering [Photo by $A$. Solarska]

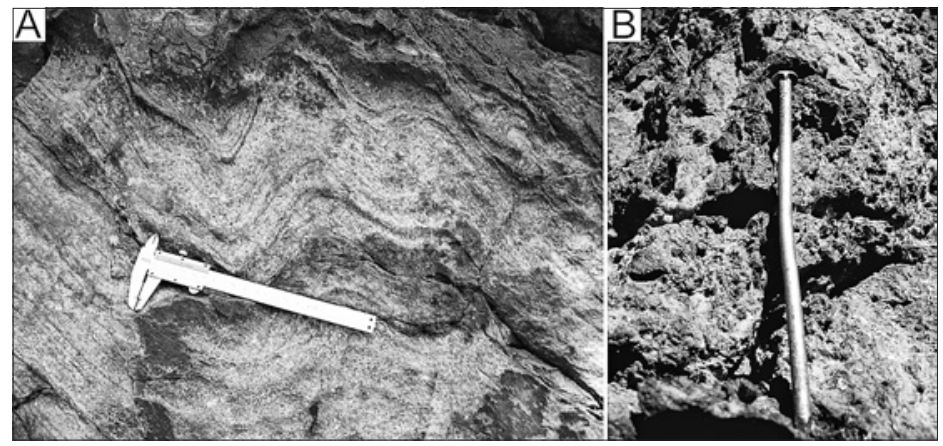

Figure 4. Tors on NW slopes of Borowa 335,5 m a.s.l. [Photo by A. Solarska]. Explanations: A - traces of former folding, C - effects of precipitation of iron and titanium
There were enumerated and briefly described in order, in which they obtain the highest, total count of points.

\section{Quarry of quartzite and quartz schist in Jegłowa} The quarry near Jegłowa is one of the few places in Poland where there are such large amounts of mountain crystals. There are specimens from 5 to ro $\mathrm{cm}$ long. The exploitation began in the seventeenth century with miners working in tunnels (Strauss, I98I, Staffa, et al. 2008). Since the half of Igth century they have begun an open pit exploitation of quartzite and quartz schist.

The quarry is about $0.4 \mathrm{~km}^{2}$ in area. The western part of the pit, which is closed, has a depth of $33 \mathrm{~m}$, a width up to $130 \mathrm{~m}$ and is about $450 \mathrm{~m}$ length. Access to the western part from the north and east is limited by almost vertical walls which reach directly to a reservoir of water (Figure 2). In the quarry there are also rocky walls accessible for tourism (Figure 3). Slag heaps were piled up on the rocky shelves (up to $30 \mathrm{~m}$ in height). It is possible that boulders can move on steeper slopes.

\section{Tors in the Gromnik massif}

There are several tors formed in denudation way. They preserve in form of two sets of tors on ridges on both sides of a small valley. Tors were build from a slate (Żelaźniewicz, 2005). These kind of rock was formed during metamorphism of marine sediments of Devonian age (about 400 million years ago) (Szuszkiewicz, et al., 2007). On the surface of tors there are visible traces of folds (Figure 4 A), which were formed during the collision of East and Central Sudetes (Żelaźniewicz, 2005). The slate has high concentration of iron (Figure $4 \mathrm{~B}$ ).

Probably because of that, there are more lightning strikes in the Gromnik massif, than in other area of the Strzelin Hills (Szuszkiewicz, et al., 2007).

\section{Zuzanka valley - small epigenetic canyon and rock outcrops}

The epigenetic gorge of Zuzanka river is found in Skalice near Henryków. It began to develop after the regression of the saalian ice sheet. In the bottom of the valley was formed a channel, which has a width up to I.5 $\mathrm{m}$ and cuts its own alluvial deposits.

There are also remnants of old river channels. They preserve in the form of a cut off, dry meanders. Tors located on the slopes show the Holocene weathering profiles and the effects of mass movements (Figure 5). Below the gorge can be spot an alluvial fan, which is not clearly visible.

In morphology of this valley there were recorded traces of an human exploitation of raw materials. Approximately $50 \mathrm{~m}$ above the breakthrough 


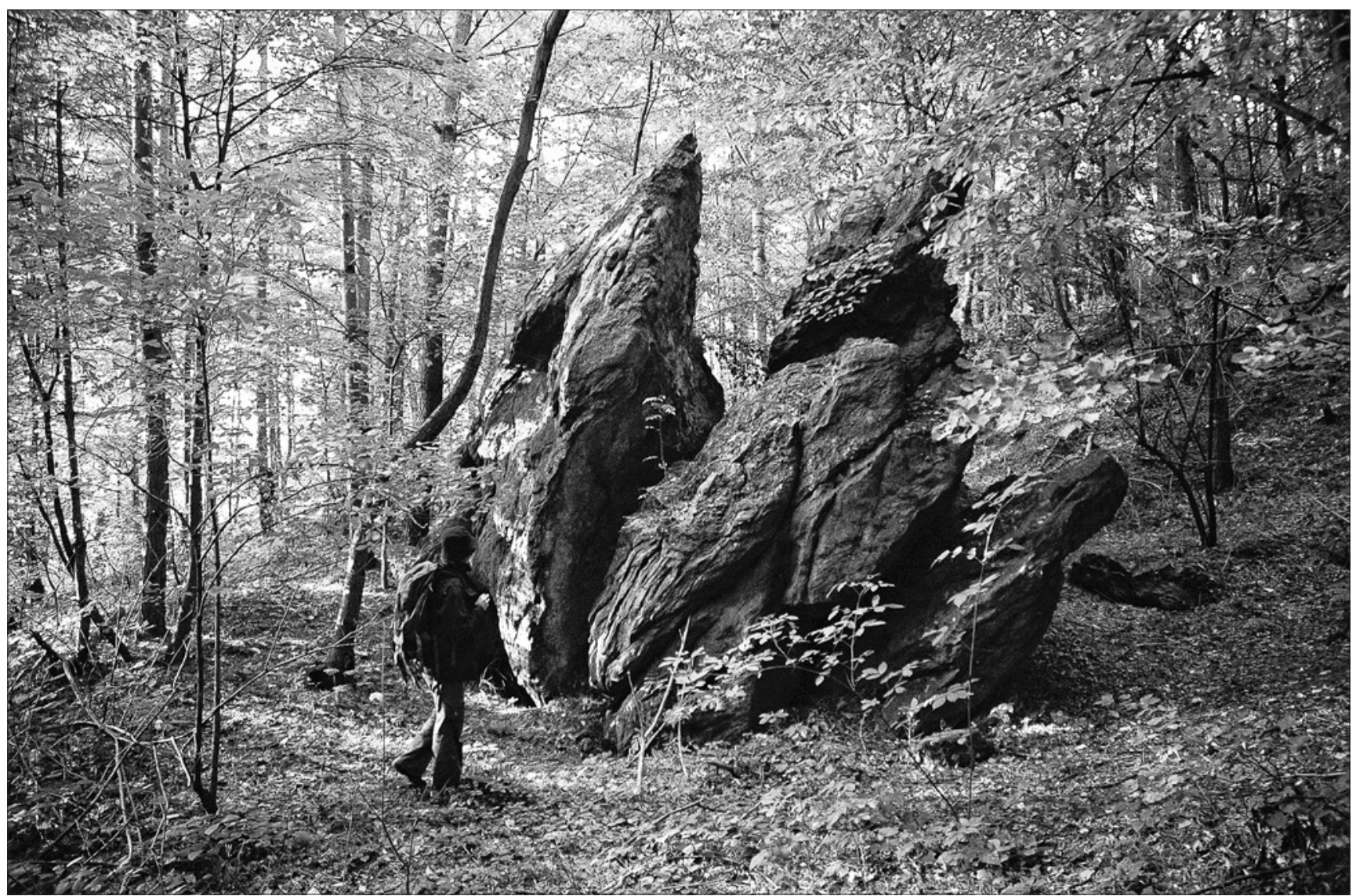

Figure 5. Results of human-made activity in the Zuzanka gorge - fragment of rock moved during exploitation [Photo by A. Solarska]

this valley was divided by dam, which is about 8 $\mathrm{m}$ high. There were located in a fish pond in the past (Figure 6).

\section{Pogródki valley-}

\section{fluvial forms with gully features}

It is a river valley, which was evolved probably as a gully in the early Holocene. Erosion of a bedrock channel led to the intersection of water-bearing strata and in the gully appeared a steady flow. The valley retains currently features of a typical gully. Its lateral branches have character of classical loess gullies (Figure 7).

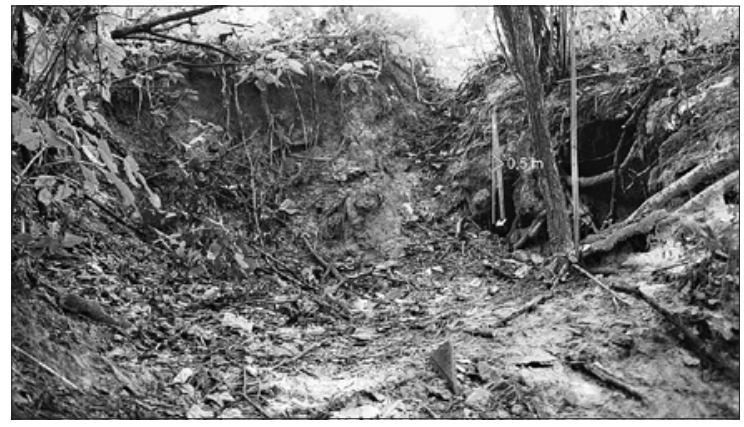

Figure 7. The upper part of one of a branch in gully system in Pogródka valley - effects of piping, developing along roots [in the background of the picture] [Photo by A. Solarska]

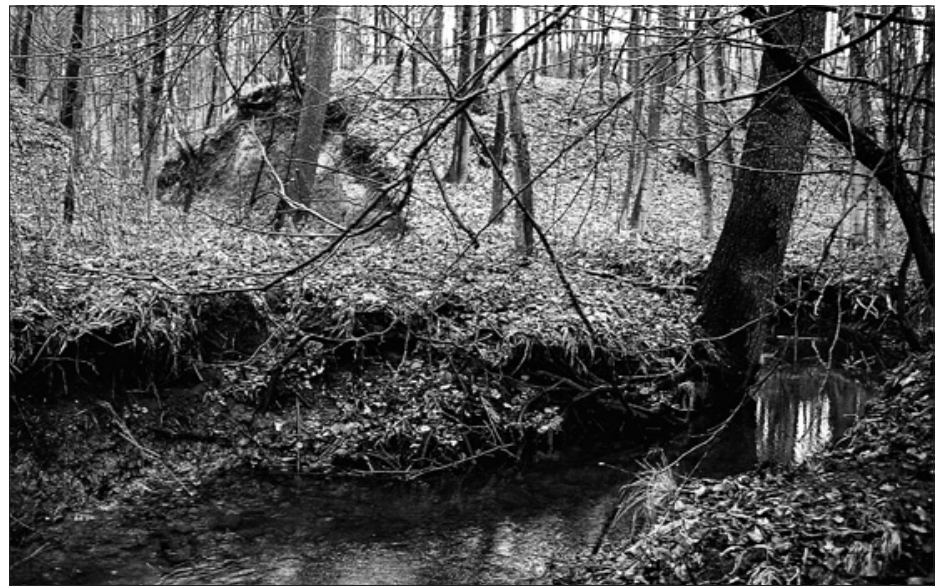

Figure 6. Selected morphological forms in the bottom of the Zuzanka gorge - former dyke, built by Cistersians, situated in the valley above the gorge [Photo by A. Solarska]

\section{Goethe's tors}

A former, small quarry of so-called date-quartzite (Szuszkiewicz, et al., 2007). These rocks are marked by elongated mineral grains looking like a date fruit. Apparently they were admired by Johann Wolfgang von Goethe during his travel to the Lower Silesia (Maliszewski I993, Szuszkiewicz et al. 2007). Initially it was an opencast mine, but there are also remains of tunnels (Figure 8). 


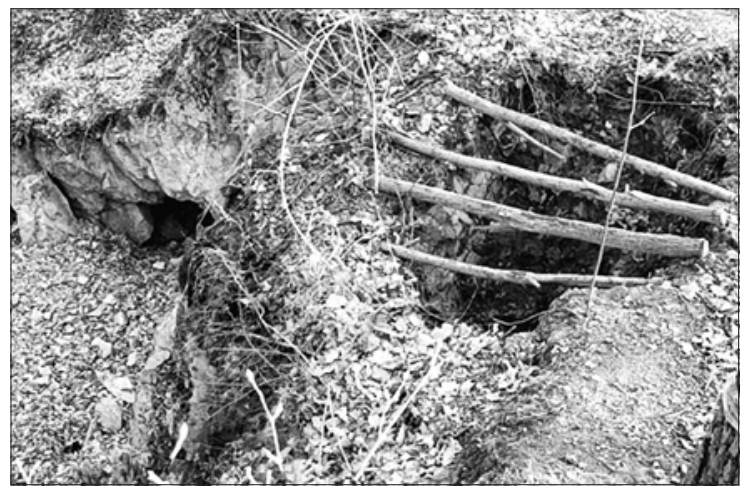

Figure 8. Goethe's tors - the former querry of quartzites near to Jeglowa [Photo by A. Solarska]

Mountain crystals occurs there in both shapes: single and crystalline-brush.

\section{Oxbow lakes and palaeochannels in Krynka valley}

There are fluvial forms representing a transformation of a channel system in the Holocene. They were preserved within a bottom of the valley at I.7 $\mathrm{km}$ section. Several generations of the cut off river bends (Figure 9) retains on both sides of the channel. Oxbow lakes are situated closest to the currently channel of Krynka river (Figure 9). They are the youngest and filled by water. Older cut off river bends were almost completely filled by mineral and organic sediments and they were called palaeochannels (Figure 9, I0). There are remains of a natural channel of Krynka river.

\section{Conclusions}

The Strzelin Hills are potentially attractive for geotourism. Geotouristic values is represented by features of the inanimate environment of the Sudetic Foreland and also some of characteristic fragments of the Sudetes. The presented geoheritage objects were selected by established valorization as geosites and geomorphosites, which have the greatest value for geotourism. They prove also the high scientific significance of the

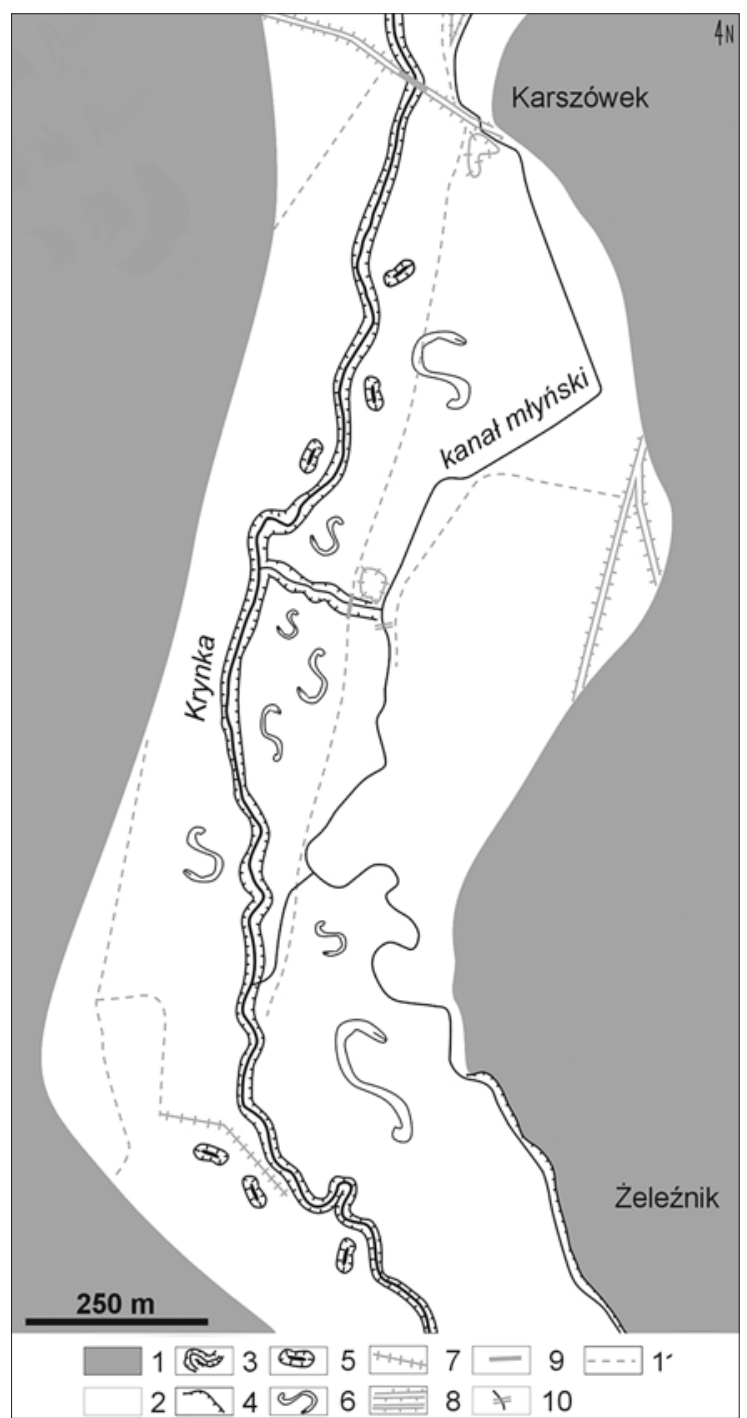

Figure 9. Geomorphological sketch of Krynka valley between Kaszówka and Karszówek.

Explanations: 1 - area outside of valley, 2 - bottom of valley, 3 - channel of the river, 4 - erosional escarpments, 5 - oxbows, 6 - palaeochannels, 7 - dikes, 8 - roads embankments, 9 - bridges, 10 anthropogenic thresholds in channels

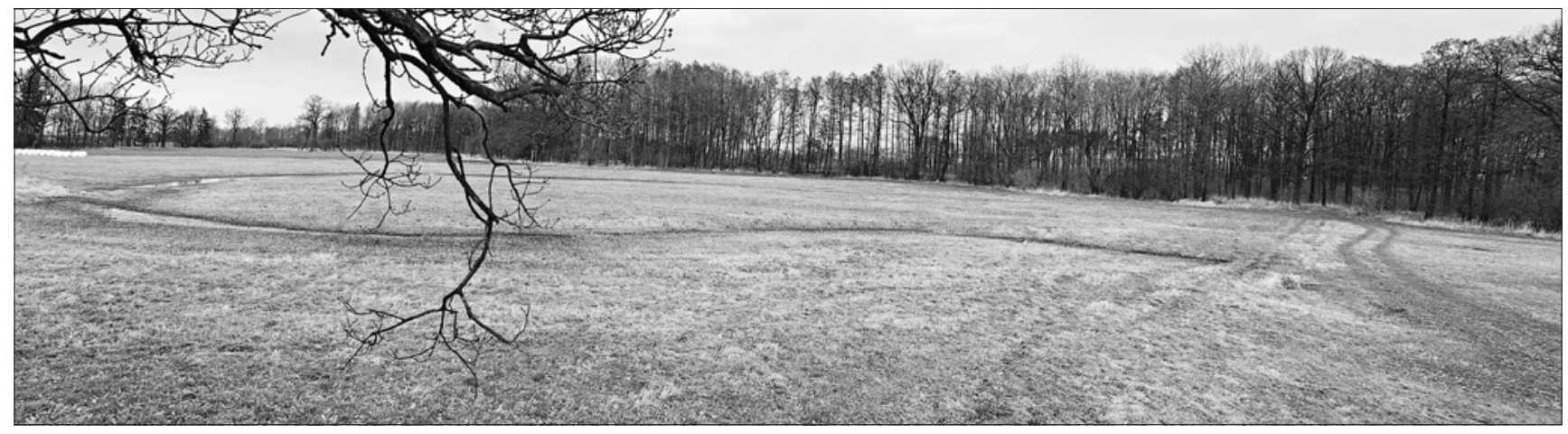

Figure 10. One of the palaeochannel in Krynka valley, partially filled by meltwater [Photo by A. Solarska] 
Strzelin Hills for geology, geomorphology and others domains. Additionally good accessibility the most of examined sites and site-sets is an important advantage for development of geotourism in the Strzelin Hills. However, there is still no geotouristic infrastructure in the Strzelin Hills to make available all their advantages for educational purposes.

In conclusion the main geotouristic values are as follow:

I. Enormous diversity of geological structure and relief in relatively small area.

2. Many closed quarries, clay, sand and gravel pits, which expose history of environmental changes and show modern geomorpholological processes.

3. Fluvial forms as a result of environmental changes in Holocene.

4. Spectacular human impacts.

\section{References}

Alexandrowicz, Z., Kuśmierz, A., Urban, J., Otęska-Budzyn, J. I992. Waloryzacja przyrody nieożywionej obszarów i obiektów chronionych w Polsce. Wyd. Państw. Inst. Geol. Warszawa, I40 pp.

Alexandrowicz, Z., Urban, J., Miśkiewicz, K. 2009. Geological Values of Selected Polish Properties of the UNESCO World Heritage List. Geoheritage I, 43-52.

Badura, J., Gawlikowska, E., Kasiński, J.R., Koźma, J., Kupetz, M., Piwocki, M., Rascher, J. 2003. Geoarpk „Łuk Mużakowa” - proponowany transgraniczny obszar ochrony georóżnorodności. Przegląd Geologiczny 5I, 54-58.

Biały, F., Czachorowska, I., Goliński, Ż., Maleczyńska, E., Pięczka, W., Radomiński, T., Restel, A., Sahaj, T., Sydor, J. I974. Strzelin. Monografia geograficzno-historyczna miasta i powiatu. Zakład Narodowy im. Ossolińskich, Wrocław, 268 pp.

Goliński, M. 2007. Dzieje zamku na Gromniku. In. Jaworski, K., Pankiewicz, A. (eds.), Gromnik. Z dziejów zasiedlenia i zagospodarowania szczytu. Wydawnictwo Instytutu Archeologii Uniwersytetu Wrocławskiego, Wrocław, 9-24.

Knapik, R., Jała, Z., Sobczyk, A., Migoń, P., Aleksandrowski, P., Szuszkiewicz, A., Krąpiec, M., Madej, S., Krakowski, K. 2009. Inwentaryzacja i waloryzacja geostanowisk Karkonoskiego Parku Narodowego i jego otuliny oraz wykonanie mapy geologicznej tego obszaru. Jelenia Góra, 5-8.
Knapik, R., Sobczyk, A., Aleksandrowski, P. 2007. Karkonoski Park Narodowy - proponowany obszar ochrony georóżnorodności w Europejskiej Sieci Geoparków. In. Štrusa J., Knapik R. (eds.), Geoekologické problémy Arkono, Sborn. Mez. Věd. Konf., říjen 2006, Svoboda n. Úpou. Opera Corcontica 44, 2, 585-592.

Maliszewski, J., I993. J. W. Goethe na Śląsku: o podróży poety w I79o roku. Państwowy Instytut Naukowy, Instytut Śląski, Opole.

Radwanek-Bąk, B. (eds.) 2009. Georóżnorodność i atrakcje geoturystyczne województwa małopolskiego. Wydawnictwo Kartograficzne „Compass”, Kraków.

Słomka, T., Kicińska-Świderska, A., Doktor, M., Joniec, A. (eds.) 2006. Katalog obiektów geoturystycznych w Polsce. Akademia Górniczo-Hutnicza w Krakowie, http://www.mos. gov.pl/kategoria/2398_katalog_obiektow_ geoturystycznych_w_polsce/, 2I.Io.20I0.

Staffa, M., Mazurski, K.R., Czerwiński, J., Pisarski, G. 2008. Wzgórza Niemczańsko-Strzelińskie. Przedgórze Paczkowskie. Słownik Geografii Turystycznej Sudetów, Wydawnictwo I-BIS, Wrocław, vol. 2I (A-M, N-Ż), Io89 pp.

Strauss, S., I98I. Strzelin i Wzgórza Strzelińskie. Zakład Narodowy im. Ossolińskich, Wrocław, 227 pp.

Szuszkiewicz, A., Madej, S., Knapik, R., 2007. Dokumentacja geologiczno-przyrodnicza wyrobisk i kamieniołomów na trasie planowanego Strzelińskiego Szlaku Kamieniołomów i Minerałów, cz. I, manuscript.

Teisseyre, A.K. I994. Spływ stokowy i współczesne osady deluwialne w lessowym rejonie Henrykowa na Dolnym Śląsku. Acta Universitatis Wratislaviensis 1586, Prace Geologiczno-Mineralogiczne 63, I88 pp.

Welc, E., 2005. Propozycje tras geoturystycznych w paśmie Magury Wątkowskiej (Beskid Niski). Geoturystyka 2, 2, 43-52.

Żelaźniewicz, A. 2005. Przeszłość geologiczna. In. Fabiszewski J. (eds.), Przyroda Dolnego Śląska, Polska Akademia Nauk Oddział we Wrocławiu, 6I-I34.

Żerelik, R. 2002. Dzieje Śląska do 1526 roku. In. Czapliński M. (eds.), Historia Śląska, Acta Universitatis Wratislaviensis 2364, I4-Iı6.

Ustawa o Ochronie Przyrody Dz.U.o9.I5I.I220

http://www.iop.krakow.pl/geosites/default.asp, 2I.ro.20Io, Polish Database of Representetive Geosites selected for The Europpean Network, Alexandrowicz Z. (ed.) 